\title{
30 лет кафедре политологии Дальневосточного федерального университета
}

10 апреля 2021 г. студенты и преподаватели кафедры политологии Дальневосточного федерального университета (ДВФУ) в весёлой неформальной обстановке интеллектуальной политологической игры отметили очередной День Политолога, посвящённый 30-летию кафедры и фракультета политологии ДВФУ.

Политология в крупнейшем университете Дальнего Востока России берёт своё начало в 1991 г., когда Учёный совет Дальневосточного государственного университета (ДВГУ) принял решение впервые осуществить набор на эту специальность. Нельзя не отметить, что поступившая в том году Марина Сергеевна Танцура и по сей день плодотворно работает на родной кафредре. Сегодня кафредра политологии Восточного института - Школы региональных и международных исследований ДВФУ - это уникальная образовательная площадка со своей историей и традициями, соединившая в себе обширный опыт в области политической науки нескольких ведущих вузов региона, которые составили фредеральный университет.

"Крёстным отцом" современной политической науки на российском Дальнем Востоке можно по праву назвать доктора исторических наук профрессора В.Ф. Печерицу. В марте 1990 г. Владимир Фёдорович стал секретарём парткома ДВГУ. В этот непростой переломный период он сумел много сделать для сохранения лучших традиций ДВГУ и перестройки высшего образования в соответствии с требованиями времени. Именно он поручил будущему первому декану (1991-1992) фракультета политологии ДВГУ Геннадию Петровичу Куликову открыть новую специальность "Политология" [2].

Необходимость открытия новой специальности и формирования такой структуры, как фракультет политологии, диктовалась двумя важнейшими обстоятельствами. Во-первых, новая наука получила в России быстрое признание, и включение подобной дисциплины в Государственный образовательный стандарт высшего профрессионального образования было вопросом времени. Во-вторых, в начале 1990-х гг. остро встал вопрос об использовании потенциала кадров учёных-обществоведов и их переквалификации в соответствии с современными требованиями [7].

Г.П. Куликов, кроме солидного опыта в преподавании общественных наук на кафедре Научного Коммунизма, имел немалый опыт руководства партийной организацией кафедр социальных наук. С единственным документом в виде выписки из протокола учёного совета ДВГУ он отправился в Москву. Министерство образования СССР уже было закрыто, и его направили в министерство образования РФ, а затем на заседание учёного совета в МГУ. Там ему удалось добиться разрешения на открытие новой специальности в ДВГУ с формулировкой "в виде исключения" [6, с. 114-115].

В настоящее время Г.П. Куликов является заместителем председателя Думы города Владивостока и преподаёт на кафедре политологии ДВФУ, делясь со студентами богатым практическим опытом работы в этом органе и Приморском отделении КПРФ.

На кафедре Политологии продолжает успешно осуществлять преподавательскую деятельность и профессор В.Ф. Печерица. Благодаря Владимиру Фёдоровичу в ДВГУ и Уссурийском государственном институте (УГПИ, позднее он вместе с ДВГУ вошёл в состав ДВФУ) создана солидная политологическая школа, которая каждый год выпускает кандидатов политических наук,

(C) Алексеев Д. Ю., 2021

АЛЕКСЕЕВ Даниил Юрьевич, канд. полит. наук, доцент кафедры политологии Дальневосточного федерального университета (2. Владивосток). E-mail: daniilalekseev@mail.ru 
защищающих свои диссертации в возглавляемом профессором В.Ф. Печерицей докторском диссертационном совете при Восточном институте - Школе региональных и международных исследований ДВФУ. Только под руководством самого Печерицы защищено около 80 кандидатских диссертаций, из них около 20 - иностранными аспирантами [2].

Официально кафедра политологии была создана в составе фракультета политологии Дальневосточного государственного университета решением его учёного совета в декабре 1991 г. Исполнять обязанности заведующего реорганизованной кафедрой было поручено Алле Сергеевне Анискевич, ранее руководившей ей под названием "кафедра Научного Коммунизма", а затем "кафедра Современного Социализма". Однако она руководила кафедрой, фактически на ней не появляясь, через звонки своему предшественнику Григорию Петровичу Овраху, который до неё семь лет руководил Кафедрой Научного Коммунизма. Вскоре А.С. Анискевич отказалась от этой должности, и с 25 июля 1992 г., исполняющим обязанности заведующего кафедрой политологии стал кандидат исторических наук Г.П. Оврах. Он стоял во главе кафедры почти 20 лет (1992-2011) и по праву считается её создателем (Неопубликованное интервью автора с заведующим кафедрой политологии в 1992-2011 годах Г.П. Оврахом от 8 мая 2021 года).

В 1992 г. Г.П. Оврах вошёл в большую группу обществоведов из ДВГУ, которые поехали в США в г. Сакраменто на месячный политологический семинар. В её составе были его коллеги по кафредре политологии: первый декан фракультета политологии ДВГУ Г.П. Куликов и его преемница на этом посту Наталья Николаевна Меньшенина, занимавшая должность декана в 1992-1996 гг. После возвращения Г.П. Оврах возглавил кафредру официально. Успела поработать на кафедре политологии и его супруга Наталья Касымовна Оврах [6, с. 117].

В 1996 г. в результате учреждения фракультета политических наук и социального управления ДВГУ кафедра политологии была преобразована в кафедру Теории и истории политики. Реорганизованный фракультет возглавил доктор исторических наук, профрессор Анатолий Михайлович Кузнецов. Оставившая должность декана Н.Н. Меньшенина создала и возглавила фракультет Мировой политики и права Дальневосточного технического университета (ДВГТУ), который позднее был преобразован в Тихоокеанский институт политики и права ДВГТУ [4].

Политология как в ДВГТУ, так и в ДВГУ явилась базой для открытия новых специальностей. В ДВГУ ими стали "Государственное и муниципальное управление" и "Международные отношения" - со своими специализациями. В 1997 г. на этой базе, в составе ДВГУ появилась уникальная структура - Владивостокский институт международных отношений Азиатско-Тихоокеанского региона (ВИМО АТР) с двумя фракультетами: фракультетом политических наук и социального управления и факультетом международных отношений. Его создание стало возможным благодаря тесному сотрудничеству ДВГУ и МГИМО МИД РФ, а также мэрии Владивостока в лице известного на всю Россию Виктора Ивановича Черепкова, часто посещавшего мероприятия фракультета политологии ДВГУ. В составе ВИМО АТР фуннкционировали 9 кафредр, причём 5 из них на фракультете политических наук и социального управления: теории и истории политики, социальной и политической антропологии, социологии, государственного и муниципального управления, массовых и политических коммуникаций. На базе института и фракультета была открыта новая для России образовательная программа по антропологии, а затем социологии со специализацией по социальной и политической антропологии [7].

Директором ВИМО АТР стал доктор политических наук, профрессор Михаил Юрьевич Шинковский, успевший в своё время поработать на кафедре Научного Коммунизма под руководством Г.П. Овраха. Его жена Наталья Витальевна Шинковская и тесть Виталий Васильевич Поляков работали в период директорства М.В. Шинковского на кафедре Теории и истории политики ДВГУ. В.В. Поляков был, кроме того, основателем кафедры политологии ДВГТУ. В 2001 г. М.Ю. Шинковский, уйдя из ДВГУ, создал и возглавил Институт международных отношений и социальных технологий Владивостокского государственного университета экономики сервиса (ВГУЭС). Он занимал эту должность до своей смерти 24 августа 2010 г. [3]. 
В 2011 г. четыре крупнейших дальневосточных вуза (ДВГУ, ДВГТУ, ТГЭУ (Тихоокеанский государственный экономический университет) и УГПИ) вошли в состав нового федерального университета. На базе кафедры теории и истории политики ДВГУ была создана объединённая кафедра политологии, которая вошла в структуру Восточного Института - Школы региональных и международных исследований ДВФУ. Кроме Г.П. Овраха на кафредре продолжали работать многолетний учёный секретарь диссертационного совета, кандидат фоллософрских наук Светлана Александровна Мефодьева, кандидаты политических наук: Антон Александрович Киреев (в 2011-2013 гг. был ответственным редактором журнала "Известия Восточного института", затем передал эту должность своему коллеге по кафедре, кандидату исторических наук Ярославу Александровичу Барбенко), Оксана Владимировна Кузьмина (впоследствии ставшая руководителем образовательной программы "Политология"), Марина Сергеевна Танцура, а также магистр политологии Анастасия Олеговна Лёвушкина. Кроме того, в состав новой кафедры вошли преподаватели из Тихоокеанского института политики и права ДВГТУ (среди них ныне работающие на кафедре кандидаты политических наук Татьяна Александровна Васильева и Екатерина Евгеньевна Нечай, а также доктор политических наук Сергей Константинович Песцов и известный на Дальнем Востоке политолог Пётр Дмитриевич Ханас) и Института управления и социальных технологий ТГЭУ (продолжающие работу на кафедре кандидаты политических наук Даниил Юрьевич Алексеев и Евгений Васильевич Булах; характерно, что к моменту слияния этим институтом руководила Н.Н. Меньшенина). К сожалению, из-за ликвидации фракультетов были потеряны и некоторые фракультетские традиции, например, посвящение в студенты-политологи, в котором принимали участие преподаватели и все старшие курсы. В сложный период реорганизации (2011-2012) заведующей кафедрой Политологии была кандидат политических наук Анна Сергеевна Паначёва, работавшая до этого деканом фракультета политических наук и социального управления ДВГУ, образовательную программу возглавил С.К. Песцов [1].

В 2012 г. кафедру политологии возглавила известный далеко за пределами Приморья политолог-практик, выпускница Тихоокеанского института политики и права ДВГТУ, кандидат политических наук Наталья Андреевна Коломейцева. Она руководила ей восемь лет (во время ухода в декрет её обязанности исполняла С.А. Мефодьева). Все эти годы Н.А. Коломейцева была душой кафедры, постоянно организовывала круглые столы, встречи и другие мероприятия, на которых студенты-политологи имели уникальную возможность запросто пообщаться с первыми лицами, представителями политической, научной и интеллектуальной элиты. Это происходило благодаря её организационной харизме и тандему с мужем-политологом Юрием Юрьевичем Коломейцевым, который руководит центром социальных инноваций "Чёрный куб". В сентябре 2020 г. кафедру политологии возглавил кандидат политических наук, руководитель образовательной программы "Международные отношения" Иван Николаевич Золотухин.

Среди выпускников, кроме уже перечисленных, можно отметить главу администрации Владивостока (2017-2018) Виталия Васильевича Веркеенко (его предшественник на этом посту (2008-2017) Игорь Сергеевич Пушкарёв в 1999 г. окончил ВИМО ДВГУ), члена Российской ассоциации политконсультантов Вячеслава Сергеевича Белякова, известного политолога и политтехнолога Павла Николаевича Наливайко и многих других [5]. К сожалению, рамки данной статьи не позволяют рассказать обо всех.

Поздравляем всех преподавателей, сотрудников, студентов и выпускников, всех, кто имел отношение к кафедре и факультету политологии, с юбилеем. Желаем им дальнейшей плодотворной работы! 


\section{Литература}

1. Алексеев Д.Ю. Вся жизнь - ДВФУ и политическое образование // Известия Восточного института. 2017. № 1. С. 127-129.

2. Алексеев Д.Ю. Отец дальневосточной политической науки // Власть книги: библиотека, издательство, вуз. 2019. Вып. 19. [Электронный ресурc]. URL: https:// www. dvfu.ru/library/almanac-power-books-/articles-almanac-19-1019/\%D0\%90\%D0\%BB $\%$ D0\% B5\%D0\%BA\%D1\%81\%D0\%B5\%D0\%B5\%D0\%B22.pdf (дата обращения: 8.05.2021).

3. Во Владивостоке скоропостижно скончался политолог Михаил Шинковский. [Электронный pecypc]. URL: https:// www.newsvl.ru/vlad/2010/08/24/nekrolog/ (дата обращения: 9.05.2021).

4. Во Владивостоке Тихоокеанский институт политики и права ДВГТУ празднует юбилей. [Электронный ресурc]. URL: https:// primamedia.ru/news/22239/ (дата обращения: 8.05.2021).

5. Интервью с выпускниками кафедры Политологии // Известия Восточного института. 2017. № 1. С. 120-126.

6. Интервью с основателями кафедры Политологии // Известия Восточного института. 2017. № 1. С. 114-119.

7. Кузнецов А.М., Оврах Г.П. О политологическом образовании на Дальнем Востоке России // Полис. Политические исследования. 1998. № 6. С. 185-186.

\section{Транслитерация по ГОСТ 7.79-2000 система Б}

1. Alekseev D.Yu. Vsya zhizn' - DVFU i politicheskoe obrazovanie // Izvestiya Vostochnogo instituta. 2017. № 1. S. 127-129.

2. Alekseev D.Yu. Otets dal'nevostochnoj politicheskoj nauki // Vlast' knigi: biblioteka, izdatel'stvo, vuz. 2019. Vyp. 19. [Ehlektronnyj resurs]. URL: https:// www.dvfu.ru/library/almanac-power-books-/articles-almanac-19-1019/\%D0\%90\%D0\%BB\%D0\%B5\%D0\% BA\%D1\%81\%D0\%B5\%D0\%B5\%D0\%B22.pdf (data obrashheniya: 8.05.2021).

3. Vo Vladivostoke skoropostizhno skonchalsya politolog Mikhail SHinkovskij. [Ehlektronnyj resurs]. URL: https:// www.newsvl.ru/vlad/2010/08/24/nekrolog/ (data obrashheniya: 9.05.2021).

4. Vo Vladivostoke Tikhookeanskij institut politiki i prava DVGTU prazdnuet yubilej. [Ehlektronnyj resurs]. URL: https:// primamedia.ru/news/22239/ (data obrashheniya: 8.05.2021).

5. Interv'yu s vypusknikami kafedry Politologii // Izvestiya Vostochnogo instituta. 2017. № 1. S. 120-126.

6. Interv'yu s osnovatelyami kafedry Politologii // Izvestiya Vostochnogo instituta. 2017. № 1. S. 114-119.

7. Kuznetsov A.M., Ovpax G.P. O politologicheskom obrazovanii na Dal'nem Vostoke Rossii // Polis. Politicheskie issledovaniya. 1998. № 6. S. 185-186.

Алексеев Д. Ю. 30 лет кафедре политологии Дальневосточного федерального университета.

Alekseev D. Yu. 30th anniversary of the Department of Political Science of Far Eastern Federal University.

Для цитирования: Алексеев Д. Ю. 30 лет кафедре политологии Дальневосточного федерального университета // Ойкумена. Регионоведческие исследования. 2021. № 2. С. 165-168. DOI: $10.24866 / 1998-6785 / 2021-2 / 165-168$

For citation: Alekseev D. Yu. 30th anniversary of the Department of Political Science of Far Eastern Federal University // Ojkumena. Regional researches. 2021. № 2. P. 165-168. DOI: $10.24866 / 1998-6785 / 2021-2 / 165-168$ 